Voureka, A. (1952). J. gen. Microbiol. 6, 352-360.

\title{
Induced Variations in a Penicillin-resistant Staphylococcus
}

\author{
BY AMALIA VOUREKA \\ The Wright-Fleming Institute of Microbiology, St Mary's Hospital \\ Medical School, London, W. 2
}

SUMMARY: When young cells of a strain of a staphylococcus were exposed to substances noxious to the organism, variations transmissible to progeny were obtained. The variations consisted mainly in a decrease in antibiotic resistance and mouse virulence. Characters of pathogenic strains such as coagulase production, mannitol fermentation and gelatin liquefaction were also abolished.

The experiments were carried out in a way that excluded the selection of spontaneous mutants. Adaptation should also be excluded as all variations consisted in a loss or decrease of activities.

The variants when first isolated seemed unhealthy, the largest part of their progeny being non-viable and consisting of cells which grew up to a point and lysed without dividing. The results obtained were therefore attributed to a damage of the parent cell caused by the injurious agents used.

Antibiotics and other substances noxious to bacteria can induce changes in bacterial cells which are transmissible to progeny for a variable number of generations. The changes have been attributed to a profound disturbance or injury of the parent cell, and in one instance it had been possible to follow, step by step, the evolution of the disturbed cells (Voureka, 1951).

The present paper deals with a strain of staphylococcus in the progeny of which decrease of virulence and of resistance to penicillin and to streptomycin were noticed after young growing cells were exposed to injurious agents.

New biological characters appeared in a few or in all the colonies grown from the treated cultures. In some cases, the new characters remained unchanged through over 50 passages in normal laboratory media, while in others the variant cell acquired one or more of the characters of the parent.

\section{EXPERIMENTAL}

To exclude, as far as can be done, the possibility that the effects obtained were due to selection of spontaneous mutants endowed with the new characters, the experiments were planned as illustrated schematically in Fig. 1.

Freshly isolated cultures derived from one pair of cocci were used in order to have as uniform a population as possible, and the experiments were carried out on a small number of cells so that all the colonies from both the control and the treated bacterial suspension could be examined.

The strain selected was a coagulase-positive, phage typable, mouse virulent strain of Staphylococcus aureus, fermenting mannitol, liquefying gelatin, producing penicillinase and giving a clear-cut zone of haemolysis on horse blood agar; it was resistant to 400 units of penicillin and to 10 units of strepto- 
mycin; it had been kept in artificial media for a long time, had a sticky consistency and the originally aureus pigment was, at the time of its use, creamy.

1.

Original isolation by micromanipulator.

One pair of staphylococci

2.

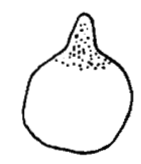

Multiplication in minute droplet of

medium in oil chamber

Transfer into broth tube and growth

4.

Dilution in broth to give 30 cocci per $0.025 \mathrm{ml}$.

5.

Further twofold dilution with

(a)

Broth

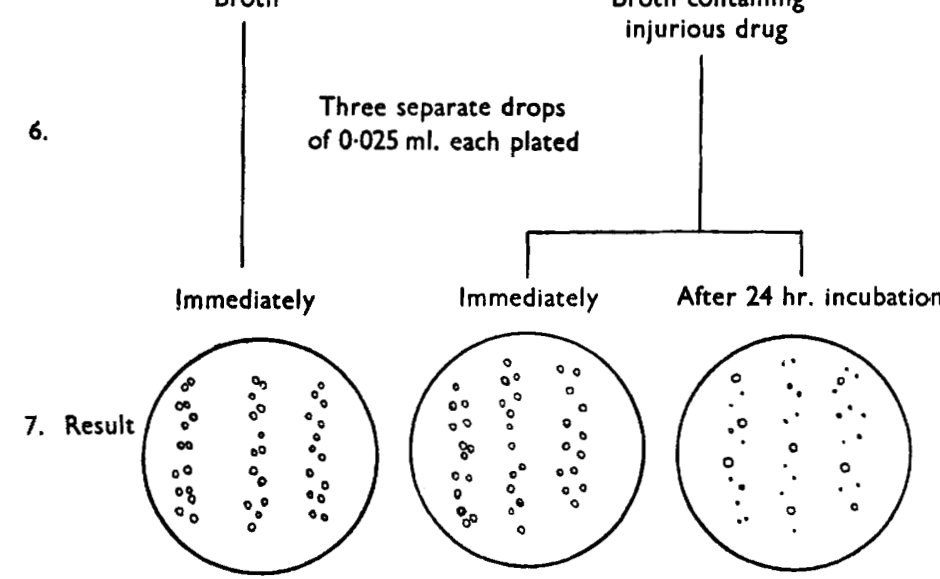

Fig. 1. Scheme of experiments.

(b)

Broth containing

njurious drug
Chloramphenicol as the injurious agent

A loopful of the freshly isolated culture was seeded into broth, left to grow for $3 \mathrm{hr}$. and then diluted in broth so that there were $c .30$ cells $/ 0.025 \mathrm{ml}$. To $0.1 \mathrm{ml}$. lots of this microbial suspension were added: (i) $0.1 \mathrm{ml}$. of broth containing $40 \mu \mathrm{g}$. of chloramphenicol, and (ii) $0.1 \mathrm{ml}$. of broth. After vigorous shaking three $0.025 \mathrm{ml}$. lots of each mixture were each allowed to run over the surface of a blood agar plate thus reducing the concentration of the drug sufficiently to allow growth. Both mixtures and plates were incubated for 
$24 \mathrm{hr}$. The plate from mixture (i) served as a control of the mixture of chloramphenicol and bacterial suspension before the drug had time to act. The plate from tube (ii) was an additional control for the suspension of staphylococci in broth. Each $0.025 \mathrm{ml}$. Iot yielded c. 15 well-separated colonies which all proved to have exactly the same characters as the parent culture.

After 24 hr. incubation the broth mixture containing chloramphenicol, in which no trace of growth was visible, was again vigorously shaken and three lots of $0.025 \mathrm{ml}$. were plated as before. The number of colonies recovered was usually less than that in the control plates. In most experiments, all, or at least some of the colonies had altered in character. Those which did not produce haemolysis on blood agar, or which showed gross divergence in colour or morphology from the control colonies were not further considered.

In some experiments the bacterial cells were exposed for a shorter time $(6 \mathrm{hr}$.) to higher concentrations of the drug $(100-125 \mu \mathrm{g} . / \mathrm{ml}$.) with similar results.

Repeated experiments with chloramphenicol gave fairly constant results when the bacterial cells were exposed to high concentrations of the drug for a period which was just sublethal.

The viable counts suggest that the concentrations used had inhibited completely the division of the cells. In order to exclude the possibility that there might have been continuous division which was balanced by an equivalent number of deaths, 1-10 pairs of staphylococci were isolated in the oil chamber of the de Fonbrune micromanipulator in droplets of drug-free nutrient medium as controls, and in the same medium containing 20 and $100 \mu \mathrm{g}$. chloramphenicol $/ \mathrm{ml}$. The medium was a filtrate of a broth culture of the original strain enriched with serum. Pairs of staphylococci were used in all manipulations instead of single cocci because the strain grew as diplococci, and any attempt to separate the pair resulted in some injury which often prevented multiplication. The preparations were held continuously at $37^{\circ}$, and observed by phase-contrast microscopy.

After 24 hr. incubation there was no division in most"of the drug-containing droplets but the cocci grew larger; on rare occasions one more pair appeared in the first $\mathbf{2} \mathrm{hr}$. without any further division. When transferred to drug-free medium some of the treated cells grew. Biological changes, similar to those described in Tables 1 and 2, were observed in two out of the three colonies yielded by a droplet containing five diplococci that had been exposed for $24 \mathrm{hr}$. to $100 \mu \mathrm{g}$. of chloramphenicol. The controls grew profusely.

\section{Other injurious agents}

Many experiments were done in exactly the same way, using penicillin in place of chloramphenicol. A few were also done using terramycin, nitrogen mustard and hydrogen peroxide. With all these substances the variants isolated were similar to those induced by chloramphenicol.

As shown in Table 1, when cells resistant to 400 units penicillin $/ \mathrm{ml}$. were exposed to high concentrations of the drug (50,000 units $/ \mathrm{ml}$.) for a sublethal 
time, cells were isolated which were highly sensitive to penicillin. These experiments were repeated many times with the same results. Since the concentration of penicillin was very high, penicillinase was added to the mixtures before plating and there was an additional control consisting of the suspension of the cells and penicillinase alone.

\section{RESULTS}

In each experiment all the colonies on the control plates were examined and were all found to have the characters of the parent strain.

Most of the variants from the treated suspensions had greatly decreased resistance to penicillin and to streptomycin, whereas there was no change in their sensitivity to chloramphenicol. Their growth was very poor, but it was markedly improved in well-aerated thin layers of broth, while the growth of the parent strain was also improved but to a much less extent. The cells had apparently acquired a greater need for oxygen and autolysed more readily in the usual broth cultures. The variant cells no longer produced coagulase; they were not attacked by the phages which lysed the parent strain nor by any of the phages normally used for typing coagulase positive strains. Their capacity to ferment mannitol, to liquefy gelatin and to produce penicillinase was also lost, but they retained their creamy pigment and were haemolytic on blood agar. One variant (variant IV) had suffered less; it remained very resistant to penicillin, although less so than the original strain, retained some resistance to streptomycin, grew well, produced coagulase and fermented mannitol, though rather slowly, and was attacked by the same phages as the original strain, though to a less extent. It should be noted that in all tests the inoculum of the variants was much greater than that of the parent strain to allow for the poorer growth of the former. All results were read after $48 \mathrm{hr}$. incubation.

Tables 1 and 2 give details of some characters studied in representative variant types on their 5th subculture on drug-free media as compared with those of the control.

Variants II-IV were subcultured 50 times in drug-free media. As a result, their growth improved; the resistance to penicillin of variants II and III increased twofold while all other characters remained unchanged; and variant IV became indistinguishable from the original strain except that it remained less resistant to penicillin and streptomycin.

All variants (except VI and VII which died) were retested after repeated subcultures over 3 months. During this period the resistance to penicillin of some variants had partly reverted. Although this resistance was in some cases considerable (100 units of penicillin/ml.) no detectable penicillinase was produced. There was also a slight reversion of the resistance to streptomycin. Coagulase activity did not reappear and phage typing was not attempted (see Table 3).

The virulence of the original strain and of the variants was compared in mice. Mice were injected intravenously (Gorrill, 1951) with $1 \mathrm{ml}$. of a thick suspension ( $24 \mathrm{hr}$. agar slope culture suspended in $\mathbf{2} \mathrm{ml}$. of saline). Four mice 
Table 1. Drug-produced variants in a strain of Staph. aureus and their biological divergence from the parent strain on their fifth subculture on drug-free media

\begin{tabular}{|c|c|c|c|c|c|c|c|c|}
\hline \multirow[b]{2}{*}{ Variants } & \multirow[b]{2}{*}{ Drug used } & \multirow[b]{2}{*}{$\begin{array}{l}\text { Concentration } \\
\text { of drug used }\end{array}$} & \multirow[b]{2}{*}{$\begin{array}{l}\text { Time of } \\
\text { exposure } \\
\text { (hr.) }\end{array}$} & \multirow[b]{2}{*}{$\begin{array}{c}\text { Growth } \\
\text { in } \\
\text { broth }\end{array}$} & \multirow[b]{2}{*}{$\begin{array}{l}\text { Phage } \\
\text { type }\end{array}$} & \multicolumn{3}{|c|}{$\begin{array}{l}\text { Degree of resistance. } \\
\text { Least concentration } \\
\text { where growth occurs }\end{array}$} \\
\hline & & & & & & $\begin{array}{l}\text { Penicillin } \\
\text { (u./ml.) }\end{array}$ & $\begin{array}{l}\text { Strepto- } \\
\text { mycin } \\
(\mathrm{u} . / \mathrm{ml} .)\end{array}$ & $\begin{array}{l}\text { Chlor- } \\
\text { amphenicol } \\
(\mu \mathrm{g} . / \mathrm{ml} .)\end{array}$ \\
\hline I & Chloramphenicol & $125 \mu \mathrm{g} \cdot / \mathrm{ml}$ & 6 & + & - & $0 \cdot 03$ & $0 \cdot 6$ & nt \\
\hline II & Chloramphenicol & $20 \mu \mathrm{g} . / \mathrm{ml}$ & 24 & + & - & 0.03 & $1 \cdot 5$ & 3 \\
\hline III & Chloramphenicol & $20 \mu \mathrm{g} . / \mathrm{ml}$ & 24 & + & - & 0.25 & $1 \cdot 5$ & 3 \\
\hline IV & Chloramphenicol & $20 \mu \mathrm{g} . / \mathrm{ml}$ & 24 & $++t$ & $47+$ & 100 & $2 \cdot 5$ & 3 \\
\hline $\mathbf{v}$ & Chloramphenicol & $125 \mu \mathrm{g} . / \mathrm{ml}$ & 6 & + & - & 0.03 & $0 \cdot 6$ & nt \\
\hline VI & Penicillin & 50,000 u. $/ \mathrm{ml}$, & 6 & + & - & 0.03 & $2 \cdot 5$ & nt \\
\hline VII & Penicillin & $50,000 \mathrm{u} . / \mathrm{ml}$ & 6 & ++ & - & $0 \cdot 03$ & $1 \cdot 25$ & nt \\
\hline VIII & Terramycin & $50 \mathrm{u} . / \mathrm{ml}$ & 6 & + & - & $0 \cdot 03$ & $1 \cdot 25$ & nt \\
\hline IX & Terramycin & $12.5 \mathrm{u} . / \mathrm{ml}$ & 6 & + & - & $0 \cdot 03$ & $0 \cdot 6$ & nt \\
\hline $\mathbf{x}$ & Nitrogen mustard & $2.5 \mathrm{mg} . / \mathrm{ml}$, & 24 & ++ & - & $0 \cdot 12$ & $1 \cdot 5$ & 3 \\
\hline $\mathbf{X I}$ & Nitrogen mustard & $2.5 \mathrm{mg} . / \mathrm{ml}$. & 24 & $+t$ & - & $0 \cdot 12$ & $1 \cdot 5$ & $\mathbf{3}$ \\
\hline XII & $\begin{array}{c}\text { Hydrogen } \\
\text { peroxide }\end{array}$ & $40 \mathrm{mg} . / \mathrm{ml}$. & 6 & ++ & - & $1 \cdot 0$ & $1 \cdot 5$ & $\mathbf{3}$ \\
\hline XIII & $\begin{array}{c}\text { Hydrogen } \\
\text { peroxide }\end{array}$ & $3 \mathrm{mg} . / \mathrm{ml}$. & 24 & + & - & 0.50 & $1 \cdot 5$ & 1.5 \\
\hline $\begin{array}{r}\text { Parent } \\
\text { strain }\end{array}$ & 0 & - & - & +++ & $47 / 47 c / 53+$ & 400 & 10 & 3 \\
\hline
\end{tabular}

All variants were coagulase negative except variant IV which showed delayed coagulation. They all showed same pigment production and haemolysis on horse blood agar as the parent strain.

$\mathrm{nt}=$ not tested $;-=$ no reaction obtained.

Table 2. Sugar fermentations of variants and parent strain

$\begin{array}{cccccc}\text { Variants } & \text { Lactose } & \text { Glucose } & \text { Dulcitol } & \text { Mannitol } & \text { Sucrose } \\ \text { I } & + & + & - & - & + \\ \text { II } & + & + & - & - & + \\ \text { III } & + & + & - & - & + \\ \text { IV } & + & + & - & \pm & + \\ \text { VI } & + & + & - & - & + \\ \text { VII } & + & + & - & - & + \\ \text { VIII } & + & + & - & \pm & + \\ \text { IX } & + & + & - & - & + \\ \text { X } & + & + & - & - & + \\ \text { XII } & + & + & - & - & + \\ \text { XIII } & + & + & - & - & + \\ \text { Parent strain } & + & + & - & + & + \\ \quad & =\end{array}$

were used for each variant, and in none was any ill effect noticed. Heart blood culture 3 days after inoculation proved to be sterile. Ten mice were inoculated each with $\mathbf{0 . 5} \mathrm{ml}$. of the parent strain in a suspension turbidimetrically one-tenth as dense. Of these eight died in $24 \mathrm{hr}$. and two became very ill and were killed on the third day; the infecting organism was recovered from the heart-blood of all ten animals. 
Table 3. Comparison of biological characters of the variants and parent strain after repeated subculture on drug-free media over 3 months

\begin{tabular}{|c|c|c|c|c|c|}
\hline \multirow[b]{2}{*}{ Variants } & \multirow[b]{2}{*}{ Growth } & \multirow[b]{2}{*}{$\begin{array}{l}\text { Coagulase } \\
\text { production }\end{array}$} & \multirow[b]{2}{*}{$\begin{array}{c}\text { Phage } \\
\text { type }\end{array}$} & \multicolumn{2}{|c|}{$\begin{array}{l}\text { Degree of resistance. } \\
\text { Least concentration } \\
\text { where growth occurs }\end{array}$} \\
\hline & & & & $\begin{array}{l}\text { Penicillin } \\
\text { (u./ml.) }\end{array}$ & $\begin{array}{l}\text { Streptomycin } \\
\quad(\mathrm{u} . / \mathrm{ml} .)\end{array}$ \\
\hline I & ++ & - & nt & 0.06 & $0 \cdot 3$ \\
\hline II & ++ & - & nt & 3 & $0 \cdot 3$ \\
\hline III & ++ & - & $\mathrm{nt}$ & 25 & $0 \cdot 6$ \\
\hline IV & +++ & + & $47 / 47 c / 53 / 54+$ & 400 & 2.5 \\
\hline VII & ++ & - & nt & $0 \cdot 03$ & $0 \cdot 6$ \\
\hline VIII & ++ & - & nt & $0 \cdot 25$ & $0 \cdot 6$ \\
\hline IX & ++ & - & nt & 0.03 & $0 \cdot 3$ \\
\hline $\mathbf{x}$ & ++ & - & nt & 3 & $2 \cdot 5$ \\
\hline $\mathbf{X I}$ & ++ & - & nt & 6 & $0 \cdot 3$ \\
\hline XII & ++ & - & nt & 50 & $1 \cdot 25$ \\
\hline XIII & ++ & - & nt & 100 & $0 \cdot 3$ \\
\hline Parent strain & $++t$ & + & $47 / 47 c / 53+$ & 400 & $2 \cdot 5$ \\
\hline
\end{tabular}

All variants showed same pigment production and haemolysis on horse blood agar as the parent strain. All except variant IV and the parent strain were coagulase negative.

nt $=$ not tested.

\section{DISCUSSION}

All the colonies on the control plates were found to have the characters of the parent strain. This seems to exclude as far as possible that the variants were present in the original culture. Sometimes all, and usually a large proportion, of the colonies obtained from the fifteen treated cells were altered. The ratio of altered to unaltered cells is thus in all cases greater than 1:15 and can hardly be that of spontaneous mutants appearing in the treated suspension and isolated through some kind of selection.

The poor and slow growth of most of the variants when first isolated, which made necessary the use of very large inocula and of longer incubation to assure growth in subsequent subcultures, also makes it improbable that these rather unhealthy cells would have survived selectively under adverse conditions and that these conditions should be presumed to favour their selection.

On repeated subcultures the growth of the variants improved. No study of these poorly growing cells and of their progeny in single cell cultures was made on this occasion. Most probably, however, the process is the same as that with variant $\beta$ of Bacterium coli $\mathrm{D} / 433$ (Voureka, 1951); that is, a large part of the progeny of the treated cell is non-viable, consisting of members which grow and lyse without dividing. When a small inoculum is used the culture may not survive, but with subcultures of large inocula on drug-free media the healthiest individuals survive by selection, the viable proportion of the progeny gradually increases and the growth improves. Although the behaviour of the variant cell was not observed under the microscope, swollen cocci and lysed swollen cells formed the largest part of the population in the 
cultures of the variants when first isolated, and this feature often persisted through many subcultures. Here again, as with variant $\beta$ of Bact. coli $D / 433$ the bacteria with altered characters isolated after treatment seemed unhealthy.

All the drugs used produced similar variations in the coccus. It would seem that it is not a question of a specific mode of action of the drugs but of attaining a certain degree of disturbance of the bacterial cell, which, when reached, has the same results. It may be that virulence and resistance to drugs in concentrations higher than those the normal members of the genus would survive are labile characters and therefore more easily changed.

The results obtained with penicillin are of interest. They seem to contradict the usual conception that exposure to a sublethal dose of penicillin tends to increase the resistance of the organism to the drug. Many have observed that increased resistance can be induced by this method. Here, however, the conditions of the experiment are not the same. The ordinary method is to start with a sensitive staphylococcus and gradually to increase the concentration as the experiment proceeds. Here we start with a penicillin-resistant staphylococcus and after one exposure to 50,000 units $/ \mathrm{ml}$. for a sublethal time, resistance is reduced.

The variations seem to consist in a loss or a reduction of activities, i.e. virulence and characters associated with it, such as coagulase production, mannitol fermentation, gelatin liquefaction; there is also a loss of penicillinase production. The loss of so many activities, the poor and slow growth, the swollen lysing cells, suggest that the cells have been severely disturbed or damaged by the drugs used. The variants have been caused to appear; they were not present in the control suspension and it is improbable that they would have appeared on the control plates if the cells had been allowed to divide only once or twice, as might have been the case in the treated suspensions.

Some of the new characters were stable; it is possible that an injury to the parent cell, caused by the noxious agents used may have resulted in some permanent alteration in its genetical structure.

Assuming that the number of genes or their pattern rule the characters of a bacterial cell, an alteration in this number or pattern would result in alterations of characters. It is not inconceivable that such alterations may appear as a result of the inflicted injury. In the cases described the alteration was lethal for many members of the progeny of the disturbed cell; they seemed to lose the capacity to divide and died after reaching a certain stage of growth. Some other members, however, survived, kept the new genetical structure and the characters it involves as a permanent feature and transmitted them to their progeny.

One thus induced mutant would have the same genetic pattern as a so-called spontaneous mutant with the same characters; and, as in spontaneous mutations, in mutations deliberately induced by adverse conditions there should be a certain distribution of frequency of the mutants with a greater incidence for more labile characters, but in the latter the rate would be expected to be much greater. 
It is possible that the only difference between spontaneous mutants and the alterations described in this paper is that while there is evidence to attribute the appearance of the latter to a lesion provoked by adverse conditions, it is not known why the former occur. It may be that spontaneous mutants also appear because of an occasional disturbance to a cell which causes it to produce among its progeny a few members with altered characters.

In a previous paper (Voureka, 1948) I showed that resistant staphylococci could be rendered sensitive to penicillin by growth with a strain of a haemolytic streptococcus. It is possible that a similar mechanism was then involved, the active streptococcus releasing substances poisonous to the staphylococci. Unfortunately, the streptococcus died before it could be thoroughly studied. Nevertheless, after mixed growth the staphylococcus recovered was either wholly sensitive or consisted of a population in which the sensitive members were far more numerous than in the controls. (The strains of staphylococcus used were genetically unstable, spontaneously producing a number of sensitive variants; Barber, 1948.)

The growth in mixed cultures had in some way either induced the appearance in the progeny of the treated bacteria of a larger number of penicillin-sensitive members or had selectively killed the penicillin-resistant ones. There can hardly be a third alternative.

\section{CONCLUSIONS}

Permanent variations can be induced in staphylococci. The conditions inducing these variations and the fact that they consist mainly in loss or decrease of activities suggest that the process through which they appear is neither a selection nor an adaptation but a result of cell damage.

When virulence was lost, other characters associated with virulence were also lost. If the variations are due, as is suggested, to an induced change of the genetic pattern or of the nuclear constitution, the simultaneous loss of all these characters might mean that they have the same or closely related genetic location.

The fact that these 'unhealthy' cells deprived of so many characters have also lost resistance to certain drugs suggests that resistance to these drugs, at least when not normal to the species, is more exacting than sensitivity, that is, involves some additional capacity.

I wish to thank Sir Alexander Fleming for his advice, help and encouragement; Prof. R. Cruickshank for his interest and suggestions; Dr R. E. O. Williams and Miss Joan Rippon (Central Public Health Laboratory, Colindale) for all phage typings; my colleague, Dr R. H. Gorrill, for helpful discussion, and Mr Ben May, Alabama, for financing this work. 


\section{REFERENCES}

BARBER, M. (1948). Sensitization of penicillin-resistant bacteria. Lancet, i, 730.

GorrIL, R. H. (1951). Experimental staphylococcal infections in mice. Brit. J. exp. Path. 32, 2.

Voureka, A. (1948). Sensitization of penicillin-resistant bacteria. Lancet, i, 62.

Voureka, A. (1951). Production of bacterial variants in vitro with chloramphenicol and specific antiserum. Lancet, i, 28.

(Received 29 October 1951) 